\title{
The Body Politic
}

Corporeal Metaphor in Revolutionary France, 1770-180o 
EDITORIAL BOARD

Jean-Marie Apostolidès

K. Anthony Appiah

Louis Brenner

Ngwarsungu Chiwengo

Jocelyne Dakhlia

Hans Ulrich Gumbrecht

Sandra Harding

Françoise Lionnet

Hervé Moulin

Gayatri Chakravorty Spivak 


\section{Mestizo Spaces \\ Espaces Métissés}

V.YT. Mudimbe EDITOR

Bogumil Jewsiewicki ASSOCIATE EDITOR 



\section{The Body Politic}

Corporeal Metaphor in Revolutionary France, 1770-180o

\section{Antoine de Baecque}

Translated by Charlotte Mandell

Stanford University Press

Stanford, California 
The Body Politic: Corporeal Metaphor in Revolutionary France, 1770-1800 was originally published in French in 1993 under the title Le Corps de l'histoire: Métaphores et politique (1770-180o) (C) 1993 Calmann-Lévy

Assistance for the translation was provided by the French Ministry of Culture.

Stanford University Press

Stanford, California

(C) 1997 by the Board of Trustees of the Leland Stanford Junior University

CIP data appear at the end of the book 
to Sylvie 
